To cite: Y Meyer 'The effectiveness of market-based initiatives for regulating development projects by multinational corporations in Africa with regard to human rights and environmental abuses ' (2019) 19 African Human Rights Law Journal 126-150

http://dx.doi.org/10.17159/1996-2096/2019/v19n1a7

\title{
The effectiveness of market-based initiatives for regulating development projects by multinational corporations in Africa with regard to human rights and environmental abuses
}

\author{
Yolandi Meyer* \\ Post-Doctoral Research Fellow, South African Research Chair in International \\ Law, University of Johannesburg, South Africa \\ https://orcid.org/0000-0003-2367-6516
}

\section{Summary}

This article analyses market-based initiatives for ensuring compliance by multinationals in Africa with specific standards, such as standards established by international financial institutions such as the International Finance Corporation, the World Bank as well as the Equator Principles and self-regulatory standards incorporated by multinationals into their operations. These initiatives are described as market-related initiatives because non-compliance could have a direct effect on a corporation's social licence to operate or its economic position in the international market. In other words, in general these initiatives involve measures that are voluntary and, strictly speaking, are not legally required, but which are complied with by corporations because of possible negative consequences associated with non-compliance. The initiatives discussed in this article include voluntary corporate social responsibility standards. The article further demonstrates how these initiatives possibly could be more effective in regulating multinational corporate activities on the continent as corporations generally seem more willing to comply with standards where non-compliance has a negative impact on the corporation's social and economic position.

\footnotetext{
* LLB LLM LLD (Pretoria); ymeyer8@gmail.com. The work is based on research supported by the National Research Foundation of South Africa (Grant No 85104).
} 
Key words: market-based initiatives; International Finance Corporation; World Bank; Africa; development

\section{Introduction}

Under the initiatives by international financial institutions the article focuses on standards set by the World Bank, specifically the private sector-funding arm of the World Bank, the International Finance Corporation (IFC). International financial institutions, such as the IFC, aim to promote economic and social development in developing countries by funding private sector projects. ${ }^{1}$ The presence and involvement of these institutions in developing countries can add legitimacy to projects and encourage additional private investment in various business ventures. ${ }^{2}$ Investors generally believe that, if an entity such as the World Bank is involved in a project, certain minimum human rights standards apply and the risk of political and financial instability is significantly reduced. ${ }^{3}$ The involvement of the World Bank can even be a precondition for the approval of a project by the major stakeholders, as was the case in the Chad-Cameroon Pipeline Project. ${ }^{4}$ This Project is a good example of the complex relationship between the desire to foster successful and economically viable projects in Africa and the pressure from civil society and other groups that these projects abide by certain minimum standards. The Project involved the construction of a 1070 -kilometer pipeline, transporting crude oil from three different Chadian oil fields to an offshore floating facility, 11 kilometres off the coast of Cameroon. ${ }^{5}$ In this case, external pressure forced investors such as the World Bank and the IFC to consider human rights implications, where previously they had refused to do so because of a conviction that such consideration would interfere in the political affairs of the host state and violate the Articles of Agreement which prohibit the consideration of factors of a political nature in the granting of a loan. ${ }^{6}$ It is because of this external pressure that the private investors agreed to abide by certain minimum human rights standards. ${ }^{7}$

1 See International Finance Corporation Our governance http://www.ifc.org/wps/ wcm/connect/corp_ext_content/ifc_external_corporate_site/about+ifc_new/ifc+ governance/ourgovernance (accessed 14 September 2017).

2 Catholic Relief Services Bottom of the barrel: Africa's oil boom and the poor (2003) 15.

3 As above; see also GH Uriz 'To lend or not to lend: Oil, human rights, and the World Bank's internal contradictions' (2001) 14 Harvard Human Rights Journal 198 where, in the context of the Chad-Cameroon Pipeline Project, the author describes the Bank as 'a lender and moral guarantor'.

4 Catholic Relief Services (n 2) 15.

5 Chad-Cameroon Pipeline Project Overview 1, http://www.ifc.org/wps/wcm/con nect/6f271e00487e8e09844ced51e3a7223f/ChadCamProjectOverview.pdf?MOD $=$ AJPERES (accessed 20 November 2016).

6 Uriz (n 3) 200; see also secs 5 and 10 of the IBRD Articles of Agreement.

$7 \quad$ Uriz (n 3) 198. 
However, in September 2008 the World Bank released a statement whereby it effectively ended its involvement in the Project. The Bank stated that during the course of the Project, the government of Chad had failed to comply with specific requirements in the loan agreement by not allocating funds to critical sectors as required by the agreement, such as education, infrastructure, health and rural development and governance. The Bank warned the government that its actions, or rather omissions, in this regard and its non-compliance with the loan agreement 'undermines the basis for the World Bank's involvement in the project' ${ }^{8}$ In 2008 the Chadian government repaid the International Bank for Reconstruction and Development (IBRD) and International Development Association (IDA) loans and officially ended the Bank's involvement in the Project. ${ }^{9}$

Notwithstanding the abundance of natural resources in some developing states, these states are severely dependant on foreign investment to fund resource extraction projects. Furthermore, multinationals and international financial institutions are vital to the process of establishing resource extraction operations and maintaining these projects to ensure the existence of a profitable venture that not only benefit the investors, but also contribute to economic and social development in the host country. However, multinationals and international financial institutions (IFIs) have a duty to ensure that their operations are in compliance with necessary human rights standards and ultimately contribute to a sustainable model of development. Standards established by IFIs and applicable to operations of multinationals in Africa could more effectively regulate corporate behaviour because of the fact that non-compliance will have severe consequences such as rescinding funding allocated for a project. Related to the activities of IFIs, the article also considers the Equator Principles as a possible regulatory hurdle with regard to the financing of projects. The article further considers self-regulatory measures such as incorporating corporate governance standards into a corporation's operations, and in this regard the article includes an assessment of the King IV principles and the UN Guiding Principles, which are widely incorporated by corporations on a domestic and global scale.

\section{International Finance Corporation}

The IFC is a member organisation of the World Bank. The World Bank is an intergovernmental organisation and a specialised agency of the United Nations (UN). It was established in 1944 as the International

8 World Bank 'World Bank statement on Chad-Cameroon Pipeline' Press release 2009/073/AFR 9 September 2008, http://www.geosint.com/images/stories/ geointelligence/study/exxon_project/WorldBank_Statement_Chad.pdf (accessed 22 November 2016). 
Bank for Reconstruction and Development (IBRD) and it aimed to facilitate the reconstruction and development of post-war Europe. ${ }^{10}$ Today the World Bank consists of the IBRD and the International Development Association (IDA), as well as other member organisations, including the IFC, the Multilateral Investment Guarantee Agency (MIGA), and the International Centre for Settlement of Investment Disputes (ICSID). The Bank's mandate has evolved from focusing on reconstruction to improving economic and social development in developing countries, and also to alleviate poverty in these areas through development projects funded by the World Bank. ${ }^{11}$ In this article mostly IFC standards are discussed, although many IFC standards are based on or draw inspiration from World Bank provisions regarding human rights and environmental protection.

With the emergence of the human rights discourse in the twentieth century it has become virtually impossible to avoid issues of human rights and environmental protection when discussing economic development. The human rights agenda has infiltrated almost every area of international law and, therefore, an effort will have to be made by international organisations to incorporate these considerations into their decision-making processes in a manner that remains consistent with the object and purpose of the organisation's existence. This necessity is true not only for international organisations such as the World Bank and the IFC, but also for economic entities such as multinationals. Market-based initiatives could be useful tools in ensuring that the activities of multinationals are kept to a certain standard.

In this regard a corporation's financial situation could be affected by not implementing these standards. This consequence could be an especially useful regulatory tool in the case of multinationals operating in Africa as regulating multinational corporate activity on the continent faces significant challenges. It especially can be difficult for African states to regulate corporate behaviour as these countries lack the institutional capacity or the political will to regulate multinational activities in their territory. This lack of will to regulate also could be due to a dependence on foreign investment. Therefore, it is imperative that host states as well as multinationals adhere to standards set by IFI's to ensure that certain regulations are adhered to in the host state which can be a more effective regulatory tool.

10 History of the World Bank, http://www.worldbank.org/en/about/history (accessed 17 October 2016); see also International Bank for Reconstruction and Development/World Bank Development and human rights: The role of the World Bank (1998) 3, http://siteresources.worldbank.org/BRAZILINPOREXTN/Resources/3817166-118 5895645304/4044168-1186409169154/08DHR.pdf (accessed 16 October 2016).

11 As above. 


\subsection{The International Finance Corporation and standards relating to the activities of multinational corporations}

The IFC can be described as the private lending arm of the World Bank. Also, it is the 'largest global development institution focused exclusively on the private sector in developing countries'. ${ }^{12}$ The IFC often finances large projects in the extractive industries sector in Africa. For example, in the last few fiscal years the IFC has funded a $\$ 50$ million oil exploration project in Kenya, a $\$ 60$ million gas exploration project in Tanzania and a $\$ 2,83$ million iron exploration project in Mozambique, to name a few. ${ }^{13}$

According to its Articles of Agreement, the purpose of the IFC is 'to further economic development by encouraging the growth of productive private enterprise in member countries, particularly in the less developed areas, thus supplementing the activities of the International Bank for Reconstruction and Development' ${ }^{14}$

According to article 3, section 9 of the Articles of Agreement: ${ }^{15}$

The Corporation and its officers shall not interfere in the political affairs of any member; nor shall they be influenced in their decisions by the political character of the member or members concerned. Only economic considerations shall be relevant to their decisions, and these considerations shall be weighed impartially in order to achieve the purposes stated in this Agreement.

12 See 'About the IFC', http://www.ifc.org/wps/wcm/connect/corp_ext_content/ifc_ external_corporate_site/about+ifc_new (accessed 17 October 2016); see also TE Lawson-Remer 'A role for the IFC in integrating environmental and human rights standards into core project covenants: Case study of the Baku-Tbilisi-Ceyhan Oil Pipeline Project' in O de Schutter (ed) Transnational corporations and human rights (2006) 393 401. See also E Morgera Corporate accountability in international environmental law (2009) 146 who described the IFC as a 'public sector institution committed to working with the private sector'.

13 See World Bank Group in Extractive Industries: 2016 Annual Review 29, http:// www.ifc.org/wps/wcm/connect/9703eec3-927a-49b6-ba33-9d8f4fd2ac63/WBGin-Extractive-Industries-2016-Annual-Review.pdf?MOD=AJPERES (accessed 10 January 2018); see also World Bank Group in Extractive Industries: 2014 Annual Review 25, http://www.ifc.org/wps/wcm/connect/4a71b8004707be599bf1ff571 43498e5/WBG+Extractive+Industies+Annual+Report+2014+FINAL.pdf?MOD=AJ PERES (accessed 12 January 2018).

14 Art 1 of the International Finance Corporation Articles of Agreement (2012). The IFC has also stated: 'Central to the IFC's development mission are its efforts to carry out investment and advisory activities with the intent to 'do no harm' to people and the environment, to enhance the sustainability of private sector operations and the markets they work in, and to achieve positive development outcomes. IFC is committed to ensuring that the costs of economic development do not fall disproportionately on those who are poor or vulnerable, that the environment is not degraded in the process, and that renewable natural resources are managed sustainably.' See International Finance Corporation's Policy on Environmental and Social Sustainability (2012) $2 \mathrm{http} / / \mathrm{www}$.ifc.org/wps/wcm/ connect/7540778049a792dcb87efaa8c6a8312a/SP_English_2012.pdf?MOD=AJ PERES (accessed 12 November 2016). See also International Finance Corporation's Policy on Environmental and Social Sustainability (2006) para 8, http://www. ifc.org/wps/wcm/connect/608f3a804942f69aaa86fe4f5ddda76e/SustainabilityPol icy.pdf?MOD=AJPERES (accessed 14 November 2016).

15 Art 3, sec 9 of the International Finance Corporation Articles of Agreement (2012). 
Environmental and social concerns, therefore, are not of primary importance to the IFC in deciding whether or not to approve a specific project for financing. The main consideration for project approval remains financial viability. If undue environmental or social harm would ensue, however, and such harm is prohibited in terms of the agreement, the project funding could be cancelled owing to noncompliance with procedures and standards as discussed below. ${ }^{16}$

Although the IFC was established in the 1950s it started considering the environmental impact of its financing operations only in the 1990s. ${ }^{17}$ In 1989 the IFC established its first formal procedure to review the environmental impact of projects. ${ }^{18}$ From 1990 onwards the IFC applied the 1988 World Bank Guidelines for evaluating projects. ${ }^{19}$ Because World Bank guidelines were drafted mainly for governments, however, it became necessary to draft a new set of standards which would be tailored to private financing activities. ${ }^{20}$

This need for a new set of standards became especially evident in 1992 when the IFC approved finance for a project in Chile which involved the construction of a series of dams as part of a hydroelectric project which would be constructed by Endesa, a privatised electric company in Chile. At that time there were no environmental regulations in Chile and, therefore, the IFC standards were of great importance in ensuring compliance with environmental standards and to prevent human rights abuses. ${ }^{21}$ For purposes of financing the project, the IFC utilised relevant World Bank directives as well as its own environmental review process. In 1995 various nongovernmental organisations (NGOs) filed a request for inspection with the World Bank Inspection Panel, which oversees accountability of World Bank operations, claiming that the IFC had not complied with the relevant World Bank directives with regard to the Chilean project. $^{22}$ Although the request was declared inadmissible as the

16 Lawson-Remer (n 12) 407.

17 See Morgera ( $n$ 12) 148. According to Morgera, during the 1990 s certain IFC projects garnered negative publicity owing to its impact on local communities, and consequently the IFC decided to incorporate environmental requirements in its contracts with clients.

18 See IFC's Policy and Performance Standards on Social and Environmental Sustainability and Policy on Disclosure of Information: Report on the First Three Years of Application 1, http://www.ifc.org/wps/wcm/connect/90f2d88046b 63bdaa9f7abb254bfb7d4/IFC_Third_Year_Report_PS_DP_.pdf?MOD=AJPERES (accessed 19 September 2017).

19 As above; see also Morgera (n 12) 148.

20 Morgera (n 12) 147.

21 MA Orellana 'Indigenous peoples, energy, and environmental justice: The Pangue/ Ralco Hydroelectric Project in Chile's Alto BioBio' (2004) 3 Centre for International Environmental Law http://www.ciel.org/Publications/Ralco_Brief_22Jul04.pdf (accessed 31 October 2016).

22 As above; see also JD Hair Pangue Hydroelectric Project (Chile): An independent review of the International Finance Corporation's compliance with applicable World Bank Group environmental and social requirements (April 1997), http:// www.sdsg.org/wp-content/uploads/2010/02/Pangue-hydroelectric-project.pdf (accessed 31 October 2016). 
Inspection Panel does not have a mandate over IFC-funded projects, ${ }^{23}$ the president of the World Bank at the time, James Wolfensohn, requested an independent review of the project by Jay Hair, the then president of the International Union for the Conservation of Nature (IUCN). ${ }^{24}$ The Report provided: ${ }^{25}$

From an environmental and social perspective the IFC added little, if any, value to the Pangue Project. Its failure to adequately supervise this project - from beginning to end - significantly increased the business risks and diminished the public credibility for both the World Bank Group (particularly IFC) and its private sector partner. There is no indication at this time (April 1997) that IFC has in place the necessary institutional operating systems, or clarity in its policy and procedural mandate, to manage complicated projects such as Pangue in a manner that complies consistently with World Bank Group environmental and social requirements and recognised best practices.

The Report recommended that the IFC adopt clear standards to apply to its operations, whether they were the World Bank standards or standards specifically tailored to IFC operations. ${ }^{26}$ The Report further stated that '[t]he IFC should develop and implement a comprehensive system of operational accountability and the institutional capacity to systematically assess, process, and effectively manage .... all IFC projects for environmental and social compliance'. ${ }^{27}$ It stressed the importance not only of incorporating environmental and social commitments into investment agreements but also of ensuring that these standards were implemented, and that progress would be monitored with sufficient systems in place to analyse compliance. ${ }^{28}$

In this regard the Report stated: ${ }^{29}$

23 The Inspection Panel has a mandate over projects funded by the IBRD and IDA. Complaints about projects funded by the IFC and MIGA are referred to the Office of the Compliance Advisor Ombudsman (CAO). See The World Bank Inspection Panel http://ewebapps.worldbank.org/apps/ip/PanellnBrief/English.pdf (accessed 15 September 2017).

24 Orellana (n 21) 4.

25 Hair (n 22) 4.

26 The Report recommended that the 'IFC needs standards by which its performance can be measured. The World Bank Group's top management team must make a decision as to whether the World Bank Group's policies and directives for managing the environmental and social impacts of projects apply to the operation of thw IFC. Assuming they do apply, that fact must be communicated clearly to the IFC staff so appropriate management systems and performance standards can be established, implemented and monitored. If some changes or adjustments in these policies are needed to make them fit IFC's mission, they should be made.' See Hair (n 22) 6.

27 Hair (n 22) 7.

28 As above.

29 Hair (n 22) 148. The report further stated: 'No aspect of our review of the Pangue Project was more troubling than the inability of IFC staff to articulate clearly what procedures it was to follow, whether the World Bank Group requirements were or were not guidelines applicable to IFC, what standards are used to ensure these requirements are met, or on what basis the current rather ad hoc approach 
[The] IFC's failure to (a) provide explicit environmental and social guidance for meeting World Bank Group standards, (b) provide specific criteria on which Pangue SA's performance would be evaluated, was (and continues to be) a very serious shortcoming of [the] IFC's overall supervision of the Pangue Project.

\subsubsection{Pre-2006 environmental and social standards}

The pre-2006 Environmental and Social Safeguards apply only to investments made before 30 April 2006. ${ }^{30}$ The pre-2006 Safeguards consist of the Disclosure Policy (1998), ${ }^{31}$ which relates to disclosure of information; the Environmental and Social Review Procedure (1998); ${ }^{32}$ Guidance Notes (1998), ${ }^{33}$ which provide additional information regarding the Environmental and Social Review Procedure; and Safeguard Policies (1998), ${ }^{34}$ which provide information and guidance to the IFC and its clients ${ }^{35}$ on how to

29 provided a mechanism for holding IFC staff accountable for it actions and results.' The Report further recommended that there 'must be independent oversight of environmental and social aspects of IFC's projects' once proper guidelines have been established, as well as a 'comprehensive system of operational accountability and the institutional capacity to systematically assess, process, and effectively manage ... all IFC projects for environmental and social compliance.' See 155-157 of the Report.

30 See Former Environmental and Social Safeguards and Supporting Materials http:// $w w w$.ifc.org/wps/wcm/connect/topics_ext_content/ifc_external_corporate_site/ifc +sustainability/our+approach/risk+management/safeguards+-+pre2006\#disclosure (accessed 24 October 2016). As an example of a pre-2006 standards project, see eg the Ghanaian Australian Goldfields Ltd Project 7261 (1996) which was a category B project due to the limited number of possible environmental impacts. Some of the main issues that were addressed as part of the environmental review included waste disposal; socio-economic impacts; rehabilitation; worker safety/ cyanide handling; land use; and cultural impacts and emissions. See Environmental and Social Review Summary for the projects, https://disclosures. ifc.org/\#/projectDetail/ESRS/7261 (accessed 16 April 2019).

31 The Disclosure Policy was replaced by the new IFC Disclosure Policy in 2006 and the IFC Access to Information Policy in 2012, http://www.ifc.org/wps/wcm/ connect/Topics_Ext_Content/IFC_External_Corporate_site/Sustainability+and+Dis closure/Disclosure+Portal (accessed 24 October 2016).

32 The 1998 version was replaced by the revised versions of the Procedure in 2006, 2007, and 2009 and 2013. For the latest version, see http://www.ifc.org/wps/ wcm/connect/topics_ext_content/ifc_external_corporate_site/ifc+sustainability/ our+approach/risk+management/environmental+and+social+review+procedure+ manual (accessed 24 October 2016).

33 The 1998 Guidance Notes were replaced by the 2006 and 2012 Guidance Notes; see http://www.ifc.org/wps/wcm/connect/topics_ext_content/ifc_external_corpor ate_site/ifc+sustainability/our+approach/risk+management/performance+standard s/environmental+and+social+performance+standards+and+guidance+notes (accessed 24 October 2016).

34 The Safeguard Policies were replaced by the Performance Standards and the Policy on Social and Environmental Sustainability in 2006 and 2012. For the Sustainability Policy, http://www.ifc.org/wps/wcm/connect/topics_ext_content/ ifc_external_corporate_site/ifc+sustainability/our+approach/risk+management/en vironmental+and+social+sustainability+policy (accessed 24 October 2016). For the Performance Standards, see http://www.ifc.org/wps/wcm/connect/topics_ext_con tent/ifc_external_corporate_site/ifc+sustainability/our+approach/risk+manageme $\mathrm{nt} /$ performance+standards/environmental+and+social+performance+standards+ and+guidance+notes (accessed 24 October 2016).

35 In this article the term 'client' includes multinational corporations. 
prevent and mitigate environmental and social harm in the planning and execution of their projects. ${ }^{36}$

The 1998 Procedure for Environmental and Social Review of Projects states, with regard to IFC projects, that 'all its operations are carried out in an environmentally and socially responsible manner', and that all IFC projects must comply with certain 'IFC environmental, social and disclosure policies'. ${ }^{37}$ Additionally, the IFC applies World Bank environmental guidelines and, where no relevant guidelines exist, it applies internationally-prescribed standards. It also is obliged to abide by the host country's domestic laws and regulations. ${ }^{38}$

The IFC Procedure for Environmental and Social Review of Projects states that the IFC 'reviews prospective projects for soundness before it invests, focusing on economic, financial, technical, legal, environmental and social issues during the project appraisal process'. ${ }^{39}$ The IFC established an Environment Division which was part of the Technical and Environment Department and responsible for reviewing, approving and supervising projects in accordance with the review procedure requirements. ${ }^{40}$

The pre-2006 framework includes several safeguard policies relevant to environmental and human rights protection. ${ }^{41}$ The pre2006 framework provides Guidance Notes that elaborate on how certain provisions should be interpreted and implemented. ${ }^{42}$

The World Bank's Pollution prevention and abatement handbook further applies to IFC-financed projects, and sets out acceptable levels of emissions and prevention and abatement measures. ${ }^{43}$ Furthermore,

36 See Former Environmental and Social Safeguards and Supporting Materials (n 30).

37 See IFC Procedure for Environmental and Social Review of Projects (1998) 1 http:/ /www.ifc.org/wps/wcm/connect/8b64370048855267ab74fb6a6515bb18/ ESRP.pdf?MOD=AJPERES (accessed 17 October 2016).

38 As above.

39 As above.

40 As above.

41 These include OP 4.01 Environmental Assessment (1998); OP 4.09 Pest Management (1998); OP 4.04 Natural Habitats (1998); OD 4.20 Indigenous Peoples (1991); OPN 11.03 Safeguarding Cultural Property (1986); OD 4.30 Involuntary Resettlement (1990); OP 4.36 Forestry (1998); OP 4.37 Safety of Dams (1996); OP 7.50 Projects on International Waterways (1998); and Child and Forced Labour Policy Statement (1998); see IFC Environmental and Social Performance Standards and Guidance Notes http://www.ifc.org/wps/wcm/ connect/topics_ext_content/ifc_external_corporate_site/ifc+sustainability/our+ap proach/risk+management/performance+standards/environmental+and+social+per formance+standards+and+guidance+notes\#pre2006 (accessed 17 October 2016).

42 The pre-2006 Guidance Notes include Guidance Note A - Checklist of potential issues for an environmental assessment; Guidance Note B - Content of an environmental impact assessment report; Guidance Note C - Outline of an environmental action plan; Guidance Note D - Outline of a project specific environmental audit; Guidance Note E - Outline of a project specific major hazard assessment; Guidance Note F - Guidance for preparation of a public consultation and disclosure plan. See IFC Environmental and Social Performance Standards and Guidance Notes (n 41).

43 See IFC Procedure (n 37) 1. 
the IFC is not authorised to finance projects that contravene host state obligations in terms of international environmental treaties. ${ }^{44}$ In this way multinationals can be held accountable for violations of primary rules of international law applicable to the host state because funding will not be provided for their operations should they contravene these international law provisions.

According to the 1998 IFC Procedure for Environmental and Social Review of Projects, projects are categorised by the Environment Division and, according to OP 4.01 (Environmental Assessment), as Category A, B, C or FI projects. The 'type, location, sensitivity, and scale of the project, as well as the nature and magnitude of its potential impact' determine the category of a project. ${ }^{45}$ Projects are classified as Category A if they are 'likely to have significant adverse environmental impacts that are sensitive, diverse, or unprecedented'. ${ }^{46}$ Category $A$ projects could have an effect on an area broader than simply that of the operation site, and they require an Environmental Impact Assessment (EIA) and an Environmental Action Plan (EAP). ${ }^{47}$ A project is classified as Category B if its 'potential[ly] adverse environmental impact on human population or environmentally important areas - including wetlands, forests, grasslands, and other natural habitats - are less adverse than those of Category A projects'. ${ }^{48}$ The impacts of Category B projects tend to be site-specific, and the scope of a Category B environmental assessment is narrower than that of a Category $A$ environmental assessment. ${ }^{49}$ Category $C$ projects are described as being 'likely to have minimal or no adverse environmental impacts' and do not require environmental impact assessments. ${ }^{50}$ Category $\mathrm{FI}$ projects 'involve [the] investment of IFC funds through a financial intermediary in subprojects that may result in adverse environmental impacts'.51

Multinationals that are funded by the IFC are further regulated by the investment agreement between the IFC and the multinational. This requirement can be an invaluable tool to ensure compliance with

$44 \quad$ IFC Procedure 2.

45 IFC Procedure 9.

46 IFC Procedure 1. Examples of Category A projects include projects affecting indigenous populations; major oil and gas developments; major industrial plants; large reservoirs and dams; projects that pose significant socio-economic risks; hazardous waste disposal operations; and transfer, manufacture and use of hazardous materials. For a complete list, see IFC Procedure (n 37) 20.

47 See IFC Procedure (n 37) 9.

48 See IFC Procedure 10. Examples of Category B projects include tourism projects; small-scale agro-industries; rural water supply and sanitation; general manufacturing; textile plants; and telecommunications. For a complete list, see IFC Procedure (n 37) 20.

49 See IFC Procedure (n 37) 10.

50 As above. Examples of Category $\mathrm{C}$ projects include factoring companies; technical assistance; life insurance companies; and mortgage securitisation. For a complete list, see IFC Procedure (n 37) 21.

51 See IFC Procedure (n 37) 10 21. Examples of Category FI projects are corporate loans to banks; private equity funds; and credit lines. 
relevant standards, as either party to the contract can terminate the agreement in case of non-compliance. The IFC investment agreement stipulates that the corporation has to comply with host country regulations as well as IFC standards. The agreement requires corporations also to submit annual environmental performance and monitoring reports. ${ }^{52}$ In addition, the IFC independently monitors social and environmental impacts of projects. ${ }^{53}$

\subsubsection{IFC Sustainability Framework 2006}

The 2006 Sustainability Framework consists of the Policy on Social and Environmental Sustainability, the Performance Standards and the Policy on Disclosure of Information. ${ }^{54}$ The Sustainability Framework [articulates the]

IFC's strategic commitment to sustainable development and is an integral part of its approach to risk management. It provides guidance on how to identify risks and deal with them, and is designed to help clients avoid and mitigate adverse impacts and manage risk as a way of doing business in a sustainable way. ${ }^{5}$

The 2006 Performance Standards consist of eight standards relating to the issues of social and environmental assessment and management systems; labour and working conditions; pollution prevention and abatement; community health, safety and security; land acquisition and involuntary resettlement; biodiversity conservation and sustainable natural resource management; indigenous peoples; and cultural heritage. 56

The approach that the 2006 Performance Standards utilises is one of negative obligations on the part of the IFC's clients. The Standards require clients to 'avoid adverse impacts on workers, communities, and the environment, or, if avoidance is not possible, to reduce, mitigate, or compensate for the impacts, as appropriate'.57 This also is the general approach that the IFC adopts with regard to its financing activities. It aims to carry out its investment activities in a 'do no harm' manner, which seeks to avoid causing damage to local communities

52 See IFC Procedure (n 37) 15.

53 IFC Procedure 16.

54 See IFC Sustainability Framework 2006 Edition http://www.ifc.org/wps/wcm/con nect/topics_ext_content/ifc_external_corporate_site/ifc+sustainability/our+approa ch/risk+management/ifcsustainabilityframework_2006 (accessed 12 November 2016). See also Morgera (n 12) 148 who states that the 2006 IFC Performance Standards can be 'considered to embody the IFC's standards for corporate environmental accountability'.

55 IFC Update of IFC's Policy and Performance Standards on Environmental and Social Sustainability, and Access to Information Policy (April 2011) iii, http:// www.ifc.org/wps/wcm/connect/fca42a0049800aaaaba2fb336b93d75f/Board-Pap er-IFC_SustainabilityFramework-2012.pdf?MOD=AJPERES (accessed 24 October 2016).

56 See 2006 Performance Standards http://www.ifc.org/wps/wcm/connect/topics ext_content/ifc_external_corporate_site/sustainability-at-ifc/policies-standards/ performance-standards/performance-standards (accessed 19 September 2017). 
and the natural environment. ${ }^{58}$ The IFC has a due diligence obligation to ensure that the possible negative impacts of a project do not outweigh its potential benefits, and that the conduct of its client will meet the requirements as set out in the Performance Standards. ${ }^{59}$

The client primarily is responsible for ensuring that its operations are conducted in a manner that is consistent with the 2006 Performance Standards and for managing the environmental and social risks of its projects. ${ }^{60}$ The IFC plays a complementary role in this regard in that it is responsible for monitoring the project to ensure that it complies with the relevant standards set by the IFC Policy. ${ }^{61}$ The IFC, therefore, reviews the project in order to establish whether it complies with relevant standards and, if not, the IFC aims to assist the client where possible to bring its conduct into compliance with the Standards. ${ }^{62}$ The Standards further recognise and support the responsibility of its clients and the private sector in general to respect human rights and to act in a socially-responsible manner when conducting its operations. ${ }^{63}$

The 2006 Policy on Environmental and Social Sustainability sets out the categorisation of projects according to their potential environmental and social impact. Similar to the programme of the pre-2006 framework, projects are categorised as Category A, B, C or FI. ${ }^{64}$ Specific standards apply to extractive industry projects, which include oil, gas and mining projects, as they carry inherently distinctive risks. With regard to these projects, the IFC specifically considers the risks regarding governance versus the benefit of the potential project. Should the risks outweigh the benefits the IFC will not support the project. The IFC further requires that revenue payments, which are made from these projects to the host government, be disclosed publicly in order to ensure transparency. ${ }^{65}$

The Performance Standards prescribe the use of environmental impact assessments and environmental management systems, which can be an effective way of ensuring compliance with relevant environmental standards as they set out a very detailed procedure that needs to be followed by a multinational to prevent any negative impact on the local environment.

In terms of the 2006 Policy on Environmental and Social Sustainability the IFC requires that its clients should have grievance mechanisms in place in order to address any concerns of the local

\footnotetext{
$58 \quad$ IFC Policy para 8.

59 IFC Policy paras 13-17.

60 IFC Policy para 5.

61 As above.

62 IFC Policy para 11.

63 IFC Policy para 8.

64 The 2012 Policy on Environmental and Social Sustainability also utilises the environmental and social categorisation of a project according to the risks its poses, namely, an A, B, C and FI categorisation. See IFC Policy (n 14) 8. 
community or anyone affected by the project. ${ }^{66}$ However, should this not occur or should it not be possible for an aggrieved party to achieve recourse in this manner, the IFC provides for a Compliance Advisor/Ombudsman ( $\mathrm{CAO}$ ), an independent body tasked with managing such complaints. ${ }^{64}$ The CAO reports to the president of the World Bank, and is independent of the IFC management. The CAO aims to resolve complaints and disputes regarding IFC-funded projects through a 'flexible problem-solving approach, and to enhance the social and environmental outcomes of projects'. ${ }^{68}$

The important role of the CAO's involvement in the oversight of IFC projects can be seen in various case studies in Africa over the last few decades. In 2004 a complaint was brought to the CAO by the First Peoples of the Kalahari against Kalahari Diamonds Ltd (KDL) operating as Sekaka Diamonds in Botswana. ${ }^{69}$ The company had received a licence to prospect in Botswana, including in the Central Kalahari Game Reserve. The complainants alleged that the project interfered with the rights of the San Bushmen to live in the reserve which is their ancestral homeland. ${ }^{70}$ In its 2005 Assessment Report the CAO found that the San people had been displaced by a policy of the government of Botswana and that the mining operations themselves had not interfered with their way of life. ${ }^{71}$ However, it also ordered that KDL continue to engage with the communities on these issues to ensure that their rights are respected. ${ }^{72}$

In another CAO case in Ghana the Vice-President of the CAO requested an investigation into IFC standards and procedures with regard to investment in deep water offshore oil and gas exploration activities. ${ }^{73}$ This investigation largely was as a result of the 2010 Gulf of Mexico oil spill in order to ensure that the IFC standards were adequate to avoid such disasters relating to deep-water exploration in future. $^{74}$ From December 2010 onwards the IFC was involved in deep-water offshore oil and gas development of the Jubilee Field 63 kilometres off the coast of Ghana. The investigation constituted a preliminary investigation and is not a full-scale CAO audit. ${ }^{75}$ The companies involved in this venture included Tullow Oil plc, Kosmos

66 IFC Policy para 31.

67 IFC Policy paras 31-34.

68 IFC Policy para 33.

69 See Compliance Advisor Ombudsman 'Botswana/Kalahari Diamond-01/Kalahari (2004) http://www.cao-ombudsman.org/cases/case_detail.aspx?id=90 (accessed 15 April 2019).

70 As above.

71 As above.

72 As above.

73 See Compliance Advisor Ombudsman 'Ghana/Tullow Oil, Kosmos Energy \& Jubilee FPSO-01/CAO Vice President Request' (2010) http://www.cao-ombuds man.org/cases/case_detail.aspx?id=166 (accessed 15 April 2019).

74 As above.

75 As above. 
Energy and other partners. ${ }^{76}$ The CAO found that the IFC adequately had assessed issues relating to a potential well blow-out and the possible consequence of such an event in accordance with relevant standards at the time. ${ }^{77}$ However, it also found that there was a 'need for the IFC to assess the relevance and applicability of the current standards and Environmental, Health, and Safety (EHS) Guidelines when the client is involved in deep water offshore oil and gas exploration, and to update such standards and guidelines to reflect new developments in good international business practices'. ${ }^{78}$

In South Africa the director of the Cradle of Life Initiative filed a complaint with the $\mathrm{CAO}$ regarding possible mining operations in the Badplaas area. ${ }^{79}$ The purpose of the Initiative is to 'conserve the Badplaas protected area and pursue sustainable eco-tourism initiatives' ${ }^{80}$ The company that was planning to launch operations in this area was Tsodilo, an exploration company that wanted to establish mining operations adjacent to or possibly overlapping the Badplaas area. ${ }^{81}$ The IFC had an equity share in Tsodilo and the complainant raised concerns regarding the possible effects of mining operations on the protected area and its environment, cultural heritage and biodiversity. ${ }^{82}$ Having considered all the relevant information, the CAO found that no further investigation was necessary, but it reserved the right to reassess the situation in future when the operations were at a more advanced stage. ${ }^{83}$

These examples are but a few of the cases considered by the CAO with regard to African projects. However, it is encouraging to note that the World Bank has an established oversight mechanism in place with regard to its funded projects to ensure that clients as well as the IFC itself comply with relevant due diligence standards relating to human rights and the environment. Such oversight is necessary in order to ensure that the standards prescribed by the IFC or World Bank are not merely considered as a tick-box exercise but are incorporated substantially into a corporation's daily operations.

\subsubsection{IFC Sustainability Framework 2012}

The 2012 IFC Sustainability Framework consists of the Policy on Environmental and Social Sustainability, which sets out the IFC's role and commitments in achieving environmental and social sustainability; the Performance Standards, which set out the client's

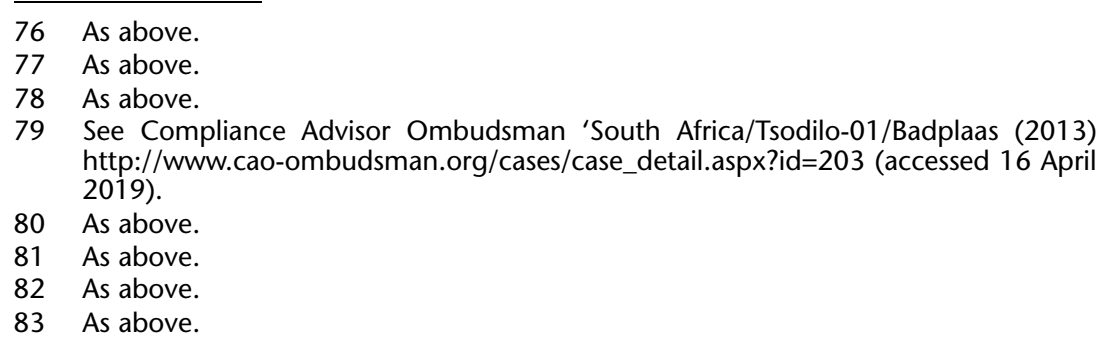


responsibility with regard to environmental and social risks and how to identify, avoid and mitigate risks; and the Access to Information Policy, which defines the IFC's commitment to transparency. ${ }^{84}$ For purposes of this section, I consider only the Policy on Environmental and Social Sustainability and the Performance Standards.

As the name indicates, the 2012 Policy on Environmental and Social Sustainability aims to achieve environmental and social sustainability. ${ }^{85}$ The Policy also stresses that the IFC has a social and environmental due diligence obligation in terms of its proposed activities. ${ }^{86}$ According to the Policy: ${ }^{87}$

Proposed investments that are determined to have moderate to high levels of environmental and/or social risk or the potential for adverse environmental and/or social impacts will be carried out in accordance with the requirements of the Performance Standards.

Managing the social and environmental risks of a project primarily is the responsibility of the client. The IFC, however, has a due diligence obligation with regard to projects, which includes the responsibility of monitoring and supervising the activities of clients to ensure that they comply with the relevant Performance Standards that are applicable to those activities. ${ }^{88}$ In cases where the standards of the host country the IFC and the World Bank differ, the most stringent standard should be applied. ${ }^{89}$

The 2012 Performance Standards support the responsibility of business to respect human rights. ${ }^{90}$ If a client does not comply with the environmental and social standards prescribed by the IFC in the legal agreements between the parties, the IFC attempts to assist the client to comply with the relevant standards. If compliance remains lacking, the IFC considers recourse and remedies. ${ }^{91}$

As far as extractive industry sector projects are concerned, for example, the IFC assesses governance risks versus the potential benefits of a project. $^{92}$ Should the risks outweigh the benefits, funding cannot be granted for a project. Extractive industry projects have to be monitored more closely as a result of weak host state

84 See IFC Access to Information Policy http://www.ifc.org/wps/wcm/connect/ 98d8ae004997936f9b7bffb2b4b33c15/IFCPolicyDisclosurelnformation.pdf?MOD =AJPERES (accessed 18 January 2018). On the link between access to information and environmental protection, see D Tladi \& L Ferris 'Environmental rights' in C Heyns \& D Brand (eds) Socio-economic rights in South Africa (2005) 249.

85 The Policy states that 'an important component of achieving positive development outcomes is the environmental and social sustainability' of IFC activities, which it tries to achieve through the implementation of the policy. See IFC Policy (n 14) 1.

86 See IFC Policy 1.

87 As above.

88 See IFC Policy (n 14) 2.

89 As above.

90 IFC Policy 3.

91 IFC Policy 5.

92 IFC Policy para 49. 
governance structures and a lack of transparency in revenue payments by the local government. ${ }^{93}$ The IFC requires public disclosure of royalty payments to the host government. ${ }^{94}$

The 2012 Performance Standards contain eight standards: assessment and management of environmental and social risks and impacts; labour and working conditions; resource efficiency and pollution prevention; community health, safety and security; land acquisition and involuntary resettlement; biodiversity conservation and sustainable management of living natural resources; indigenous peoples; and cultural heritage.

Performance Standard 1, namely, the assessment and management of environmental and social risks and impacts, requires clients to 'respect human rights, which means to avoid infringing on the human rights of others and address adverse human rights impacts business may cause or contribute to'. 95 This requirement implies a negative duty on the part of the client, which also requires the client to exercise a certain level of due diligence when conducting its operations. This standard mainly requires that the client evaluate environmental and social risks, mitigate risks and impacts if avoidance is not possible, and provide for grievance mechanisms should negative impacts occur. ${ }^{96}$

Performance Standard 3, which addresses resource efficiency and pollution prevention, aims to promote the sustainable use of natural resources and to avoid or mitigate environmental harm. ${ }^{97}$ Performance Standard 4, community health, safety and security, 'recognises that project activities, equipment, and infrastructure can increase community exposure to risks and impacts'. This standard relates to the impact that environmental degradation can have on human safety and security, which aptly demonstrates the important interplay between the issue of human rights and the environment. The client, therefore, is required to avoid or where it is not possible to avoid, to mitigate these risks and impacts. ${ }^{98}$

Performance Standard 6, biodiversity conservation and sustainable management of living natural resources, stresses the importance of managing and conserving natural resources and biodiversity in order to achieve sustainable development. The standard is influenced by the

\footnotetext{
93 As above.

94 IFC Policy 11.

95 See Performance Standard 1 of IFC Performance Standards on Environmental and Social Sustainability (2012), http://www.ifc.org/wps/wcm/connect/115482804a0 255db96fbffd1a5d13d27/PS_English_2012_Full-Document.pdf?MOD=AJPERES (accessed 12 November 2016).

96 As above. It is interesting to note that Performance Standard 1 applies to social and environmental impacts of projects only within their 'area of influence' which is described as the 'area likely to be affected by the project'. This provision is very similar to that of the Global Compact provision, which provides for a 'sphere of influence' concept.
}

97 See Performance Standard 3 (n 95).

98 See Performance Standard 4 (n 95). 
Convention on Biological Diversity ${ }^{99}$ and, unlike some of the other standards, contains more direct obligations on clients. This standard requires clients to 'protect and conserve biodiversity' and to 'promote the sustainable management of living natural resources'. These duties imply a positive duty on the part of the client. The standard, however, contains also a negative duty inasmuch as it requires clients to avoid negative impacts on biodiversity and ecosystems and, if avoidance is not possible, to mitigate the effects. ${ }^{100}$

\section{Equator Principles}

The Equator Principles are a voluntary ${ }^{101}$ set of principles developed by private sector banks, and are based on the IFC Performance Standards on Social and Environmental Sustainability and the World Bank Environmental, Health and Safety Standards. ${ }^{102}$ The Equator Principles are defined as 'a risk management framework, adopted by financial institutions, for determining, assessing and managing environmental and social risk in projects and is primarily intended to provide a minimum standard for due diligence to support responsible risk decision-making'. ${ }^{103}$

Financial institutions that sign up to the Equator Principles commit themselves to refrain from providing loans to clients that do not comply with the relevant social and environmental standards prescribed by the Principles. ${ }^{104}$ The Equator Principles apply to all industry sectors and state that the projects that they finance should aim to avoid negative environmental impacts or, where these are unavoidable, to minimise or mitigate negative impacts. ${ }^{105}$ Equator Principles Financial Institutions (EPFIs) consider themselves as having a duty to respect human rights and to exercise a certain level of due diligence in their investment activities in accordance with the Principles. In this respect the Principles also reference the Guiding Principles on Business and Human Rights and the Protect, Respect, Remedy Framework as the origins of this duty. ${ }^{106}$

99 See Convention on Biological Diversity 1992.

100 See Performance Standard 6 (n 95).

101 The Principles state: 'Financial institutions adopt and implement the Equator Principles voluntarily and independently, without reliance on or recourse to the IFC, the World Bank Group, the Equator Principles Association, or other EPFIs.' See The Equator Principles (June 2013) 11, http://www.equator-principles.com/ index.php/ep3/ep3 (accessed 28 November 2016).

102 The Equator Principles: Frequently asked questions, http://equator-principles.com/ resources/Frequently\%20Asked\%20Questions.pdf (accessed 28 November 2016); see also Morgera (n 12) 169.

103 See 'About the Equator Principles' http://www.equator-principles.com/index.php/ about-ep/about-ep (accessed 14 November 2016).

104 The Equator Principles: Frequently asked questions (n 102).

105 The Equator Principles 2 \& 3.

106 As above. 
A project has to comply with the requirements of all ten Principles in order to qualify for funding. Projects are reviewed and categorised according to risk into Category A, B and C, similar to the World Bank categorisation system. The Principles require a client to undertake an environmental and social assessment for Category $A$ and $B$ projects in order to establish the risks and possible impacts of the project. ${ }^{107}$ The Principles further require that the project should comply with relevant host state laws and standards related to environmental and social issues. In some cases the project should also comply with IFC Performance Standards and World Bank Group Environmental, Health and Safety Guidelines (EHS Guidelines). ${ }^{108}$

With regard to Category $A$ and $B$ projects clients are required to provide and maintain an Environmental and Social Management System (ESMS) as well as an Environmental and Social Management Plan (ESMP). ${ }^{109}$ The Principles also require an independent environmental and social consultant to review documentation such as the ESMS and the ESMP. ${ }^{110}$

In order to manage compliance the Equator Principles provide for covenants. They state in Principle 8 that '[f]or all projects, the client will covenant in the financing documentation to comply with all relevant host country environmental and social laws, regulations and permits in all material respects'. Should the client not comply with the relevant environmental and social covenants, the EPFI works with the client in order to remedy the situation and bring the client back into compliance with these standards. ${ }^{111}$

Although the Equator Principles are voluntary and do not provide for any substantial enforcement mechanism, it is encouraging to see that the Principles are based on IFC and World Bank provisions and that, in that way, they ensure the continuity and consistency of standards relating to international financial activity. The Equator Principles, similar to the IFC or World Bank Standards, find their strength in the fact that EPFls can withhold financing in case of noncompliance, thereby effectively rendering them binding for all practical purposes on any potential investment operations by multinationals.

107 Principle 2 of The Equator Principles (n 102).

108 Principle 3 of The Equator Principles.

109 Principle 4 of The Equator Principles. As part of the ESMS, clients are required to provide for a grievance mechanism; this is according to Principle 6 of the Equator Principles.

110 This only applies to Category A projects and certain Category B projects. See Principle 7 of The Equator Principles.

111 Principle 8 of The Equator Principles. 


\section{Self-regulation and corporate social responsibility}

Self-regulation is discussed to illustrate how multinationals can utilise self-regulatory initiatives in order to make international norms directly applicable to their operations. Corporations have made environmental protection a priority because of consumer concerns regarding transparency and corporate responsibility. ${ }^{112}$ The issue of selfregulation has become a popular topic, especially when considering new and innovative ways of regulating multinational activity. Selfregulation initiatives can take many forms including, but not limited to, codes of conduct, disclosure and transparency agreements and social labels. ${ }^{113}$ According to Utting and Clapp, corporate social responsibility (CSR) refers to 'a range of initiatives adopted by companies, business associations and so-called multi stakeholder entities that aim to promote ethical corporate behaviour and minimize the negative impact of business activity on society and the environment' ${ }^{114}$

CSR exists mainly as a result of the commitments made by business entities at the Rio Conference where various entities agreed voluntarily to alter the way they operate in order to ensure that a more sustainable model of business is followed in the future. This initiative was supported by various international NGOs. ${ }^{115}$ CSR initiatives, such as codes of conduct, are a popular type of self-regulatory tool, which has been utilised by multinationals, especially in the last few decades. ${ }^{116}$ These codes prescribe certain minimum standards for the manner in which multinationals conduct their operations. The codes also can specify in which types of countries the multinational should invest, in order to prevent the multinational operating in a country vulnerable to human rights abuses and to set out standards for business partners and subsidiaries of the multinational operating abroad. 117

One obvious major shortcoming of corporate codes of conduct is that they apply only to those multinationals that decide to adopt them. Codes of conduct require independent monitoring and enforcement mechanisms by objective third parties to be truly effective, which normally is not the case. ${ }^{118}$ Moreover, these codes of

112 D Shelton \& A Kiss Guide to international environmental law (2007) 67.

113 A Gatto Multinational enterprises and human rights obligations under EU law and international law (2011) 18-19, citing CSR Europe and Ashridge Centre for Business and Society Exploring business dynamics. Mainstreaming corporate social responsibility in a company's strategy, management and systems (2002) 9.

114 J Clapp \& P Utting 'Corporate responsibility, accountability, and law: An introduction' in P Utting \& J Clapp (eds) Corporate accountability and sustainable development (2008) 1.

115 Clapp \& Utting (n 114) 2.

116 Clapp \& Utting 1.

117 S Joseph Corporations and transnational human rights litigation (2004) 7.

118 Joseph (n 117) 8. 
conduct generally are not legally binding. They, however, could be binding on a multinational in the sense that the corporation incorporates these regulatory standards into its operations and effectively binds itself to these standards through incorporation and internalisation. Some of these codes of conduct could be made applicable to a multinational's subsidiaries or subcontractors operating abroad. 119

An important method to ensure compliance in cases of selfregulatory initiatives being utilised is to require companies to report on their progress with regard to the incorporation of corporate social standards. In order to comply with corporate social responsibility requirements companies generally have to draft reports on the impact their operations have on the environment and the local communities. Companies usually make these reports available on their websites. However, there also are organisations, such as the Global Reporting Initiative (GRI), that set specific requirements for company reporting. The organisation then places these reports on its website and this practice adds some transparency to the process of submitting a company report. The GRI primarily considers issues of environmental and sustainable development and, therefore, the focus of the reports is on these issues. ${ }^{120}$

CSR initiatives have proved to be successful in some instances, especially as multinationals consider self-regulation not to be an invasive and formal method of regulation. Multinationals, therefore, have more control to decide how and when regulations are to be applied and, by giving them a sense of control over the process, they tend to be more willing to comply with set standards. Therefore, it is not difficult to envision that the system could be flawed precisely because of the level of control that multinationals have over the process of regulation. Factors, such as a lack of transparency, a lack of independent monitoring and voluntary commitments drafted too vaguely, contribute to self-regulation being considered an ineffective regulatory method. ${ }^{121}$

It is very rare that self-regulation initiatives are applied objectively and effectively. Most multinationals simply cannot regulate their own activities without some degree of bias or subjectivity. Consumers, therefore, often view self-regulation efforts as a mere tool used to foster public relations and improve a multinational's image among its consumers or clients without it having the necessary positive impact

119 Gatto (n 113) 18-20.

120 Gatto (n 113) 22; Global Reporting Initiative, https://www.globalreporting.org/ information/about-gri/Pages/default.aspx (accessed 17 March 2015). Also see A de Jonge Transnational corporations and international law: Accountability in the global business environment (2011) 28; Joseph (n 117) 7.

121 Gatto (n 113) 22. 
on the local environment in host states. ${ }^{122}$ For example, Royal Dutch Shell adopted one of the most extensive codes of conduct in the 1990s after the negative environmental and social impact of its operations in Nigeria had come to light. After its adoption the code seemed to have little impact on the welfare of local communities. In fact, in some communities the situation surrounding environmental degradation and human rights abuses worsened. ${ }^{123}$

For these reasons many scholars do not favour this system of regulation. For example, Duruigbo argues that insufficient international standards and weak domestic regulatory frameworks have led to many multinationals embracing the concept of selfregulation. ${ }^{124}$ These initiatives, however, have proven to be ineffective in most cases as a result of factors such as the voluntariness of the initiatives, the lack of transparency, vagueness of regularity provisions and a lack of remedies available to injured parties. ${ }^{125}$ Duruigbo advocates obligatory initiatives to regulate corporate activities as voluntary codes have thus far proved to be mostly ineffective. ${ }^{126}$ In a sense the voluntary initiatives discussed in this article fall somewhere between an obligatory initiative and a voluntary initiative because of the fact that there are more concrete consequences in cases of noncompliance with the initiatives discussed in the article, such as a loss of social standing or loss of profit, even if it may be marginal in some cases.

Market-related methods of regulation can be useful in the right circumstances where compliance is monitored effectively and without bias. Self-regulation remains an important tool in prompting multinationals to do business in a more sustainable way. It is necessary, however, that the process of self-regulation becomes more transparent and that sufficient monitoring takes place to ensure that corporations are held accountable for non-compliance or, alternatively, that sufficient repercussions for non-compliance exist even if only in the form of an effect on the company's licence to operate.

Examples of two initiatives that have proven to be quite effective at ensuring the internalisation of corporate governance standards by companies are the South African King IV Principles on the domestic level, and the UN Guiding Principles on the global level. Although these principles are not legally binding, they have become so widely accepted by the business community as constituting good corporate

122 As above; S Joseph 'An overview of the human rights accountability of multinational enterprises' in MT Kamminga \& S Zia-Zarifi (eds) Liability of multinational corporations under international law (2000) 83.

123 Kamminga \& Zia-Zarifi (n 127) 9; see n 12 above.

124 EA Duruigbo Multinational corporations and international law: Accountability and compliance issues in the petroleum industry (2003) xxi.

125 As above.

126 Duruigbo (n 129) 128-129. 
governance that numerous companies have incorporated these principles into their corporate governance structures.

The King IV Principles build on the King III Principles and have been revised to include the most up-to-date international corporate governance codes and practices. King IV was published in 2016 and is applicable to financial years starting from 1 April $2017 .{ }^{127}$ King IV is a set of voluntary principles and practices. Some principles of corporate governance have been incorporated into legislation in South Africa, and should there be a conflict between the law and the King IV Principles the domestic law will prevail. ${ }^{128}$ Should the King IV Principles be more prescriptive, then the higher standard of care should be followed. ${ }^{129}$ Voluntary principles, such as the King IV Principles, could evolve into binding rules and can inform national legislative decision making. Furthermore, should a voluntary principle be widely practised to a sufficient extent, it could evolve into a standard of care which is recognised by the courts. ${ }^{130}$ According to the KPMG King IV Summary Guide: ${ }^{131}$

Whilst King IVTM is not law, the governance outcomes achieved and the practices adopted and implemented will likely become the criteria by which the required standard of care and appropriate standards of conduct of the governing body and its members are measured.

Moreover, for a company to be registered on the Johannesburg Stock Exchange (JSE) it has to comply with certain aspects of the King IV Principles as a listing requirement and non-compliance with corporate governance practice, which includes the King IV Principles, could also lead to board liability in some circumstances. ${ }^{132}$ The King IV Principles are drafted to apply to all sectors irrespective of form. However, the principles should be tailored to specific organisations' needs as a onesize-fits-all approach rarely is effective and could become nothing more than a tick-box exercise. ${ }^{133}$

The United Nations Guiding Principles on Business and Human Rights $^{134}$ are based on three core principles, namely, the state obligation to respect, protect, and fulfil human rights. Business enterprises have specific functions and are required to respect human

127 KPMG King IV summary guide (2016) 2 https://assets.kpmg.com/content/dam/ $\mathrm{kpmg} / \mathrm{za} / \mathrm{pdf} / 2016 / 11 /$ King-IV-Summary-Guide.pdf (accessed 4 July 2018).

128 Institute of Directors Southern Africa King IV Report on corporate governance for South Africa (2016) 35.

129 Institute of Directors (n 133) 76.

130 Institute of Directors 35.

131 KPMG (n 132) 3.

132 Werksmans Attorneys 'A Review of the King IV Report on Corporate Governance' (2016) 25 https://www.werksmans.com/wp-content/uploads/2013/05/061741 WERKSMANS-king-iv-booklet.pdf (accessed 15 April 2019).

133 Institute of Directors (n 133) 35.

134 Report of the UN Special Representative of the Secretary-General on the Issue of Human Rights and Transnational Corporations and Other Business Enterprises, Ruggie (Guiding Principles). See also the report of the Independent Expert on the Issue of Human Rights Obligations Relating to the Enjoyment of a Safe, Clean, 
rights, which necessarily includes the duty to respect the environment as these rights are 'inherently interdependent'. Furthermore, effective remedies are required when rights and obligations are breached. ${ }^{135}$ The duty to respect is considered to be a 'global standard of expected conduct' regardless of where a corporation operates, and it is independent also of a state's duty to protect. ${ }^{136}$ The duty to respect primarily involves acting with due diligence. ${ }^{137}$ The due diligence obligation is not an unusual or novel legal construct as most companies already have existing due diligence structures as part of larger risk management systems. 138 The reasons for the incorporation of due diligence measures generally are economically or strategically driven. ${ }^{139}$ Companies incorporate due diligence measures in order to comply with statutory and common law requirements of due diligence and further to protect themselves from civil and criminal liability in the case of alleged human rights violations. ${ }^{140}$

The Guiding Principles provide a sound and legally authoritative framework, which is accompanied by an implementation plan that is structured in such a manner that all relevant parties know what their responsibilities are regarding the business and human rights agenda. The normative contribution of the Guiding Principles lies not in the creation of new international law obligations but rather in elaborating the implications of existing standards and practices for states and businesses, integrating them within a single, logically coherent and comprehensive template and identifying where the current regime

Healthy and Sustainable Environment, JH Knox A/HRC/22/43 (24 December 2012) para 10. See further the report of the Special Rapporteur on the Issue of Human Rights Obligations Relating to the Enjoyment of a Safe, Clean, Healthy and Sustainable Environment para 2 which states: 'A safe, clean, healthy and sustainable environment is necessary for the full enjoyment of a vast range of human rights, including the rights to life, health, food, water and development.'

135 Guiding Principles (n 139) 1.

136 Guiding Principles 13.

137 The Guiding Principles define due diligence in this context as 'a comprehensive, proactive attempt to uncover human rights risks, actual and potential, over the entire life cycle of a project or business activity, with the aim of avoiding and mitigating those risks'. See also the Human Rights Council, Report of the Special Representative of the Secretary-General on the Issue of Human Rights and Transnational Corporations and Other Business Enterprises: Business and human rights: Towards operationalising the 'protect, respect and remedy' framework para 71.

138 See Global Risk Affairs: Human Rights Due Diligence (I): Corporate Social Responsibility meets Compliance (3 May 2013) http://www.globalriskaffairs.com/ 2013/05/human-rights-due-diligence-i-corporate-social-responsibility-meets-com pliance/ (accessed 24 April 2017). See also MB Taylor, L Zandvliet \& M Forouhar 'Due diligence for human rights: A risk-based approach' Corporate Social Responsibility Initiative Working Paper 53 (2009) https://www.hks.harvard.edu/mrcbg/CSRI/publications/workingpaper_53_taylor_etal.pdf (accessed 21 April 2017).

139 Taylor, Zandvliet \& Forouhar (n 143) 6.

140 Taylor, Zandvliet \& Forouhar 5. 
falls short and how it should be improved. ${ }^{141}$ Several companies have demonstrated their support for the Guiding Principles and are involved in a process of reporting their progress with regard to the implementation of the Guidelines, including companies such as BHP Billiton, BP, Microsoft, Nestlé, Unilever, Shell and Total, to name a few. ${ }^{142}$

\section{Conclusion}

Morgera states that the IFC Performance Standards 'reinforce the growing expectation in the international community that private companies should contribute to biodiversity conservation and sustainable development, and behave in a preventative and participatory manner with regard to their use of natural resources'. ${ }^{143}$

The fact that environmental conditions can be included in financing agreements between IFls and clients (such as multinational corporations) means that private financing could be an effective method of regulating the activities of multinationals. These conditions become contractually binding and, consequently, if the company does not comply with the provisions, the contract could be cancelled and financing withdrawn. ${ }^{144}$ Therefore, it may be considered a very effective market-related mechanism which, if not complied with, can have serious financial consequences for a corporation including losing funding for a particular project owing to non-compliance with certain standards. The IFC is bound also by international environmental law as a result of its degree of international legal personality and, therefore, it is not authorised to finance activities that are in contravention of its duties in terms of international law. ${ }^{145}$

The IFC believes that environmentally and socially sustainable business practices could increase the profitability of investments and also ensure a competitive advantage for its clients. These practices also improve the reputation of the IFC and ensure that it can continue to promote its development agenda effectively in countries where it is most needed. ${ }^{146}$

One could argue that an IFI can be held legally responsible for lending to a client who engages in activities that violate human rights and environmental standards. An IFI has a due diligence duty to

141 J Ruggie Guiding principles on business and human rights: Implementing the United Nations 'protect, respect and remedy' framework A/HRC/17/31 (21 March 2011) 6; Guiding Principles on Business and Human Rights 5 http://www.ohchr.org/ Documents/Publications/GuidingPrinciplesBusinessHR_EN.pdf (accessed 19 April 2017).

142 UN Guiding Principles Reporting Framework https://www.ungpreporting.org/ database-analysis/explore-disclosures/ (accessed 28 August 2018).

143 Morgera (n 12) 171.

144 Morgera 144.

145 P Sands Principles of international environmental law (2012) 1025.

146 IFC Policy (n 14) para 7. 
ensure that a project complies with international as well as host country standards before investing in the project. In this regard Brodnig states that '[w]hile states remain the major duty-holders in implementing the right to development, international organisations have important complementary responsibilities in fostering international cooperation'. ${ }^{147}$

Self-regulatory initiatives, on the other hand, can persuade multinationals to adopt rules applicable to their operations in order to improve their overall social image and commit themselves to a higher standard of doing business as it makes good business sense to do so. This commitment occurs through the process of self-regulation, where corporations implement initiatives such as corporate codes of conduct or other self-regulatory initiatives in order to make international rules applicable to their operations. These codes are directly legally binding in that a corporation internalises the provisions, thereby agreeing to be bound. Examples of such internalisation include companies adopting the King IV Principles or the Guiding Principles, as previously discussed. The process of self-regulation requires objective oversight and monitoring to be truly effective, elements which are often lacking with regard to self-regulatory efforts by multinationals. However, it is encouraging to see that corporations in fact are willing to incorporate restrictive rules in order to be bound by principles of environmental and human rights whether for the sake of the well-being of people and the environment or for window dressing. In the end, the result is the same.

What this article aims to illustrate is that market-based initiatives, such as funding requirements by IFIs or the implementation of selfregulatory measures and social considerations into the corporate governance structures of businesses, can be effective in ensuring that corporations are held to a certain standard of conduct. In some ways this practice can be more effective than other international regulatory initiatives because the result of non-compliance is experienced directly by corporations through, for example, an effect on a corporation's licence to operate or a loss of profits owing to non-compliance with standards set by IFIs.

147 See G Brodnig 'The World Bank and human rights: Mission impossible?' (2002) 17 The Fletcher Journal of Development Studies 7. 